\title{
Analisis Kecacatan Produk Tiang Listrik Beton Menggunakan Metode Seven Tools dan New Seven Tools (Studi Kasus: PT. Kunango Jantan)
}

\author{
Dewi Diniaty ${ }^{1}$, Sandi $^{2}$ \\ ${ }^{1,2}$ Jurusan Teknik Industri, Fakultas Sains dan Teknologi, UIN Sultan Syarif Kasim Riau \\ Jl. HR. Soebrantas No. 155 Simpang Baru, Panam, Pekanbaru, 28293 \\ Email: dewidiniaty@uin-suska.ac.id, sandifms3@yahoo.com
}

\begin{abstract}
Abstrak
PT. Kunango Jantan merupakan sebuah industri yang memproduksi Tiang Listrik Beton dan telah mendistribusikan hasil produksinya ke seluruh penjuru sumatra seperti Jambi, Palembang, Medan, Padang, Aceh dan daerah lainnya. Permasalahan pada perusahaan ini yaitu masih banyak terdapat jumlah produk cacat dan gagal (reject) ketika dalam proses produksinya.Tujuan penelitian ini adalah menganalisa faktorfaktor penyebab terjadinya produk gagal/reject dan menganalisa tindakan perbaikan yang harus dilakukan. Penulis menggunakan metode seven tools untuk mengetahui penyebab dari terjadinya produk gagal/rejectdan metode newseven toolsyang digunakan untuk melihat tindakan perbaikan yang harus dilakukan berdasarkan faktor penyebab terjadinya produk gagal/reject. Berdasarkan pengolahan data diperoleh bahwa perbaikan produk reject/gagal yang diprioritaskan untuk perbaiki adalah kategori pecah dengan persentasi sebanyak $35,97 \%$, kategori keropos/ bolong sebesar 35,25\% dan kategori tipis sebelah sebesar 12,95 \%. Adapun solusi yang diusulkan kepada pihak manajemen perusahaan adalah dengan memeriksa dan merawat mesin atau tools yang digunakan secara berkala, meningkatkan kualitas bahan baku, memperbaiki lingkungan kerja, meningkatkan sumberdaya manusia (SDM) dengan melakukan pelatihan dan membuat SOP pada setiap stasiun serta unit kegiatan kerja.
\end{abstract}

Kata Kunci : Produk gagal/reject, Seven Tools dan New Seven Tools

\section{Pendahuluan}

Indonesia merupakan salah satu negara berkembang di dunia yang memerlukan pembangunan secara masif untuk menunjang sarana prasarana dan meningkatkan perekonomian masyarakat. Industri manufaktur bidang infrastruktur memegang peranan penting proses pembangunan tersebut. Sehingga industri infrastruktur berusaha menciptakan produk yang berkualitas untuk meyakinkan kontraktor agar mempercayai produk yang dihasilkan. Karena umumnya pada proyek besar pihak kontraktor sangat mementingkan keselamatan, terutama keselamatan saat pelaksanaan proyek maupun keselamat penggunaan infrastruktur yang telah selesai dibangun. Selain itu bagi perusahaan, mengendalikan kualitas dengan baik juga dapat menguntungkan pihak perusahaan sebab semakin sedikit produk yang cacat (kualitas buruk) maka dapat mengurangi biaya perbaikan (repair), inventori, bahan baku dan waktu kerja yang berdampak pada profit perusahaan. Metode untuk mengontrol stabilitas proses dan mengendalikan kualitas produksi yang bisa digunakan yaitu metode
Seven Tools dan NewSevenTools. Metode SevenTools merupakan alat statistik untuk mencari akar penyebab permasalahan kualitas sehingga dapat mengendalikan kualitas. Sedangkan metode NewSevenTools merupakan alat bantu dalam memetakan masalah secara terstruktur, guna membantu perbaikan kualitas produksi Tiang Listrik Beton.

\section{Metode Penelitian}

Penelitian dilakukan di lantai produksi PT. Kunango Jantan. Langkah pertama yang dilakukan adalah mengidentifikasi proses produksi di lantai produksi, kemudian dilanjutkan dengan pengumpulan data sekunder melalui wawancara dan dokumentasi. Hasil identifikasi akan diketahui bagianmana dilantai produksi yang sangat vital dalam rangka menjamin kualitas produk.Identifikasi mulai dari awal untuk memetakan masalah-masalah sampai dengandirumuskan usulan perbaikan dengan menggunakan metode new sevendan new seven tools.

Pengolahan data pertama dilakukan dengan menggunakan tools-tools dari metode seven 
tools seperti flowchart, histogram, peta kendali-p dan diagram pareto. Kemudian selanjutnya dilakukan analisa terhadap hasil dari pengolahan data yang telah dilakukan sebelumnya. Analisa data ini dilakukan menggunakan metode Seven Tools dan metode NewSeven Tools. Analisa menggunakan metode Seven Tools dilakukan dengan Diagram Sebab-Akibat (Fishbone). Sedangkan analisa menggunakan metode NewSeven Tools dilakukan dengan Affinity Diagram, Tree Diagram, dan Process Dicision Program Chart.

\section{Hasil dan Pembahasan}

\section{Flowchart}

Flowchart pada bagian ini menggambarkan seluruh aktivitas kegiatan yang dilalui perusahaan dari bahan baku datang hingga proses pendistribusian produk Tiang Listrik Beton. Berikut merupakan Flow Chart produksi PT. Kunango Jantan.

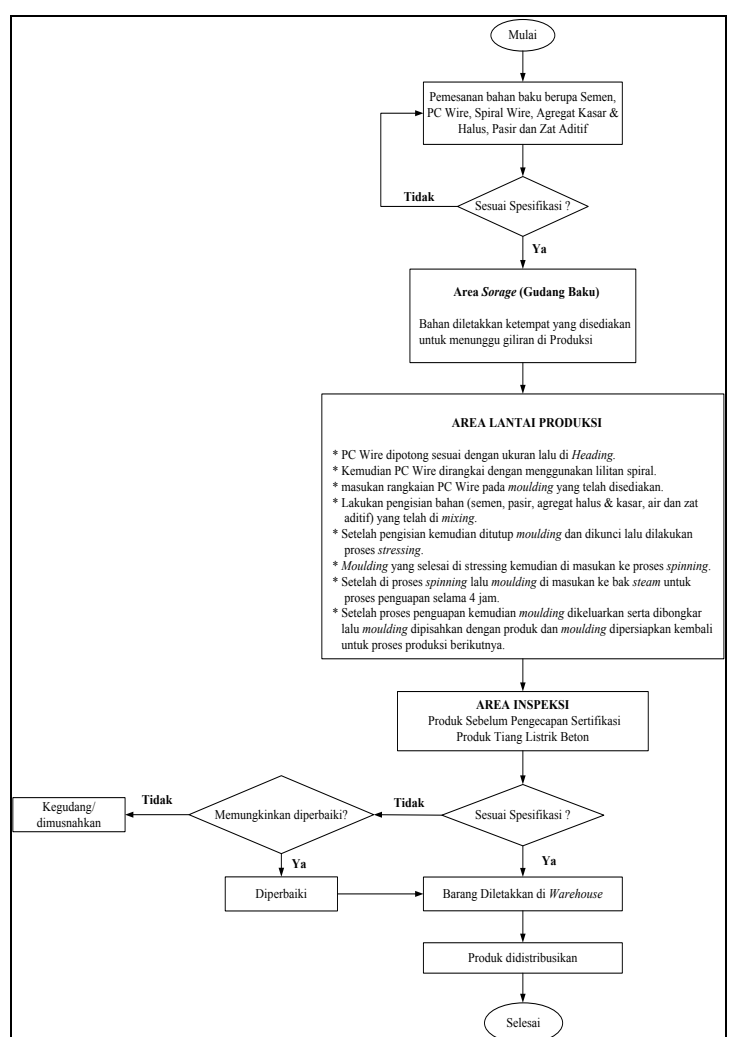

Gambar 1. Flow Chart Proses Produksi PT. Kunango Jantan

\section{Histogram}

Histogram merupakan suatu alat yang digunakan untuk menyajikan data secara grafis untuk melihat kecenderungan pada setiap elemen data. Histogram juga digunakan untuk membuat rangkuman data sehingga data mudah dianalisis.
Adapun Histogram dari data jenis kecacatan Produksi Tiang Listrik Beton di PT. Kunango Jantan adalah sebagai adalah sebagai berikut:

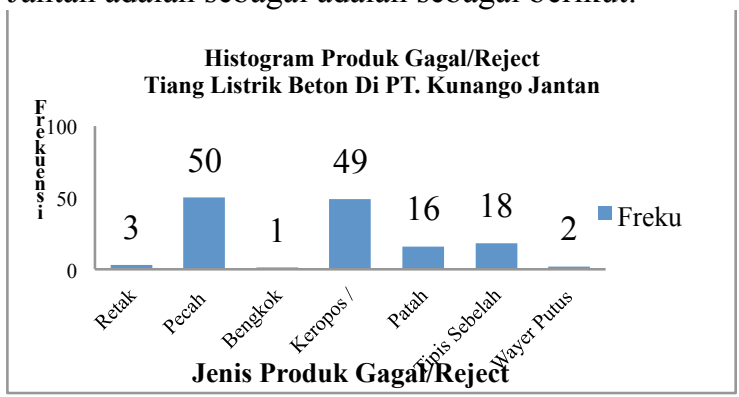

Gambar 2.Histogram Kecacatan Produksi Tiang Listrik Beton di PT. Kunango Jantan

\section{Peta kendali}

Peta kendali digunakan untuk mengetahui apakah proporsi produk reject yang dihasilkan melewati batas kontrol atau tidak. Untuk membuktikanya maka peneliti melakukan suatu perhitungan dengan menggunakan peta kendali-P. Berikut tahapan perancangan peta kendali-P:

1. Menghitung Proporsi

Perhitungan diatas menggunakan program Microssoft Excel 2010. Berikut merupakan cara menghitung proporsi jumlah kecacatan secara manual pada Sub Grup pertama :

Rumus :

$$
\begin{array}{cc}
P= & \frac{\text { Jumlah cacat }}{\text { Jumlah diperiksa }} \\
P & =\frac{4}{1472} \\
P & =0,003
\end{array}
$$

Pada Sub Grup selanjutnya menggunakan cara yang sama. Berikut merupakan tabel rekapitulasi perhitungan proporsi kecacatan:

Tabel 1. Rekapitulasi Proporsi dan Persentase produk Reject Tiang Listrik Beton

\begin{tabular}{|c|c|c|c|c|c|}
\hline No & Bulan & $\begin{array}{c}\text { Jumlah } \\
\text { Produk } \\
\text { Gagal/Reject }\end{array}$ & $\begin{array}{c}\text { Jumlah } \\
\text { Produksi } \\
\text { Bulanan }\end{array}$ & $\begin{array}{c}\text { Proporsi } \\
(P)\end{array}$ & Persentase \\
\hline 1 & February & 4 & 1472 & 0,003 & 4,520 \\
\hline 2 & Maret & 6 & 1554 & 0,004 & 6,422 \\
\hline 3 & April & 25 & 3166 & 0,008 & 13,134 \\
\hline 4 & Mei & 31 & 2260 & 0,014 & 22,814 \\
\hline 5 & Juni & 8 & 1613 & 0,005 & 8,249 \\
\hline 6 & Juli & 13 & 1480 & 0,009 & 14,610 \\
\hline 7 & Agustus & 34 & 2780 & 0,012 & 20,342 \\
\hline 8 & September & 18 & 3021 & 0,006 & 9,910 \\
\hline \multicolumn{7}{|c|}{ Jumlah } & 139 & 17346 & 0,060 & 100 \\
\hline
\end{tabular}

2. Menghitung Garis Tengah, UCLp (Upper Control Limit Sub-grup) dan LCLp (Lower Control Limit Sub-Grup).

a. Menghitung Garis Tengah.

Berikut adalah perhitungan garis tengah menggunakan rumus:

$$
\begin{gathered}
\bar{p}=\frac{\sum_{\mathrm{i}=1}^{\mathrm{k}} \mathrm{x}_{\mathrm{i}}}{\sum_{\mathrm{i}=1}^{\mathrm{k}} \mathrm{n}} \quad(2) \\
\bar{P}=\frac{139}{17346}=0,008
\end{gathered}
$$


b. Menghitung UCLp (Upper Control Limit Sub-grup)

Berikut merupakan perhitungan UCLp menggunakan Rumus:

$$
\begin{aligned}
& \mathrm{UCL}_{\mathrm{p}}=\overline{\mathrm{p}}+3 \sqrt{\frac{\overline{\mathrm{p}}(1-\overline{\mathrm{p}})}{\mathrm{n}_{\mathrm{i}}}} \\
& \mathrm{UCL}_{\mathrm{p}}=0,008+3 \sqrt{\frac{0,008(1-0,008)}{1472}} \\
& \mathrm{UCL}_{\mathrm{p}}=0,008+3 \sqrt{\frac{0,008(0,992)}{1472}} \\
& \mathrm{UCL}_{\mathrm{p}}=0,008+3 \sqrt{\frac{0,0079}{1472}} \\
& \mathrm{UCL}_{\mathrm{p}}=0,015
\end{aligned}
$$

c. Menghitung LCLp (Lower Control Limit Sub-grup)

Berikut merupakan perhitungan LCLp menggunakan Rumus:

$$
\begin{aligned}
& \mathrm{LCL}_{\mathrm{p}}=\overline{\mathrm{p}}-3 \sqrt{\frac{\overline{\mathrm{p}}(1-\overline{\mathrm{p}})}{\mathrm{n}_{\mathrm{i}}}} \\
& \mathrm{LCL}_{\mathrm{p}}=0,008-3 \sqrt{\frac{0,008(1-0,008)}{1472}} \\
& \mathrm{LCL}_{\mathrm{p}}=0,008-3 \sqrt{\frac{0,008(0,992)}{1472}} \\
& \mathrm{LCL}_{\mathrm{p}}=0,008-3 \sqrt{\frac{0,0079}{1472}} \\
& \mathrm{LCL}_{\mathrm{p}}=0,001
\end{aligned}
$$

\begin{tabular}{|c|c|c|c|c|c|c|c|}
\hline $\begin{array}{l}\mathrm{N} \\
\mathrm{O}\end{array}$ & $\begin{array}{c}\text { Bula } \\
n\end{array}$ & $\begin{array}{c}\text { Jumlah } \\
\text { Produk } \\
\text { Gagal/Rejec } \\
t\end{array}$ & $\begin{array}{l}\text { Jumlah } \\
\text { Produksi } \\
\text { Bulanan }\end{array}$ & $\begin{array}{l}\text { Proporsi } \\
(P)\end{array}$ & $\begin{array}{c}\text { UCL } \\
\mathrm{p}\end{array}$ & $\begin{array}{c}\mathrm{LCL} \\
\mathrm{P}\end{array}$ & $\begin{array}{l}\text { Garis } \\
\text { Tengah }\end{array}$ \\
\hline 1 & $\begin{array}{l}\begin{array}{l}\text { Febr } \\
\text { uary }\end{array} \\
\end{array}$ & 4 & 1472 & 0,003 & $\begin{array}{c}0,01 \\
5\end{array}$ & 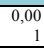 & 0,008 \\
\hline 2 & $\begin{array}{c}\text { Mar } \\
\text { et }\end{array}$ & 6 & 1554 & 0,004 & $\begin{array}{c}0,01 \\
5\end{array}$ & $\begin{array}{r}0,00 \\
1\end{array}$ & 0,008 \\
\hline 3 & $\begin{array}{c}\text { Apri } \\
1\end{array}$ & 25 & 3166 & 0,008 & $\begin{array}{c}0,01 \\
3\end{array}$ & $\begin{array}{r}0,00 \\
3\end{array}$ & 0,008 \\
\hline 4 & Mei & 31 & 2260 & 0,014 & $\begin{array}{c}0,01 \\
4\end{array}$ & $\begin{array}{r}0,00 \\
2\end{array}$ & 0,008 \\
\hline 5 & Juni & 8 & 1613 & 0,005 & $\begin{array}{c}0,01 \\
5\end{array}$ & 0,00 & 0,008 \\
\hline 6 & Juli & 13 & 1480 & 0,009 & $\begin{array}{c}0,01 \\
5\end{array}$ & $\begin{array}{r}0,00 \\
1\end{array}$ & 0,008 \\
\hline 7 & $\begin{array}{l}\begin{array}{l}\text { Agu } \\
\text { stus }\end{array} \\
\end{array}$ & 34 & 2780 & 0,012 & $\begin{array}{c}0,01 \\
3\end{array}$ & $\begin{array}{r}0,00 \\
3\end{array}$ & 0,008 \\
\hline 8 & $\begin{array}{l}\text { Sept } \\
\text { emb } \\
\text { er }\end{array}$ & 18 & 3021 & 0,006 & $\begin{array}{c}0,01 \\
3\end{array}$ & $\begin{array}{r}0,00 \\
3\end{array}$ & 0,008 \\
\hline \multicolumn{2}{|c|}{ Jumlah } & 139 & 17346 & & & & \\
\hline
\end{tabular}

Perhitungan UCLp dan LCLp pada subgrup berikutnya dilakukan dengan dengan cara yang sama. Berikut merupakan hasil rekapitulasi yang dihitung menggunakan Program Microssoft Excel 2010 .

Tabel 2 Rekapitulasi Nilai Garis Tengah, UCLp dan LCLp Produk Tiang Listrik Beton

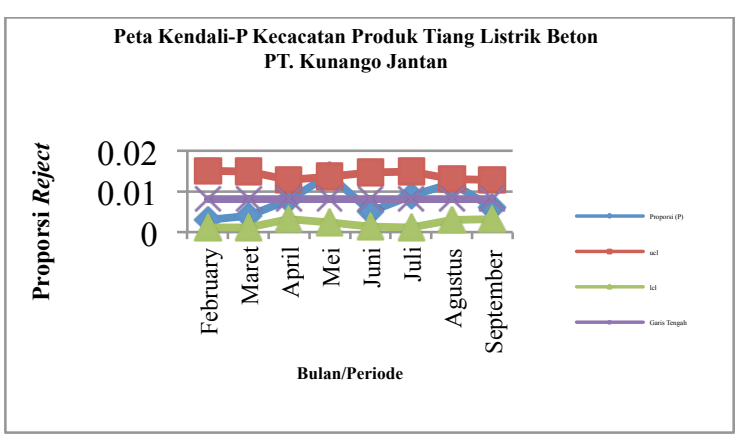

Gambar 3. Peta Kendali-P Produk Reject PT. Kunango Jantan

\section{Diagram pareto}

Diagram pareto merupakan diagram yang menggambarkan prioritas permasalahan yang mesti diambil tindakan (perbaikan). Berikut merupakan data yang menunjukkan jumlah produk reject/gagal, persentase dan persentase komulatif produk reject/gagal pada produk Tiang Listrik Beton. Perhitungan menggunakan program microssoft excel 2010.

Tabel 3. Data Jumlah Produk Reject/Gagal, Persentase dan Persentase Komulatif Produk Reject/Gagal Pada Produk Tiang Listrik Beton

\begin{tabular}{|c|l|c|c|c|}
\hline No & Produk Cacat & Frekuensi & $\begin{array}{c}\% \\
\text { Frekuensi }\end{array}$ & $\begin{array}{c}\% \\
\text { Frek.Kumulatif }\end{array}$ \\
\hline 1 & Pecah & 50 & 35,97 & 35,97 \\
\hline 2 & $\begin{array}{l}\text { Keropos } \\
\text { Bolong }\end{array}$ & 49 & 35,25 & 71,22 \\
\hline No & Produk Cacat & Frekuensi & $\begin{array}{c}\% \\
\text { Frekuensi }\end{array}$ & $\begin{array}{c}\% \\
\text { Frek.Kumulatif }\end{array}$ \\
\hline 3 & Tipis Sebelah & 18 & 12,95 & 84,17 \\
\hline 4 & Patah & 16 & 11,51 & 95,68 \\
\hline 5 & Retak & 3 & 2,16 & 97,84 \\
\hline 6 & Wayer Putus & 2 & 1,44 & 99,28 \\
\hline 7 & Bengkok & 1 & 0,72 & 100,00 \\
\hline \multicolumn{2}{|l}{ Jumlah } & $\mathbf{1 3 9}$ & $\mathbf{1 0 0}$ & \\
\hline
\end{tabular}




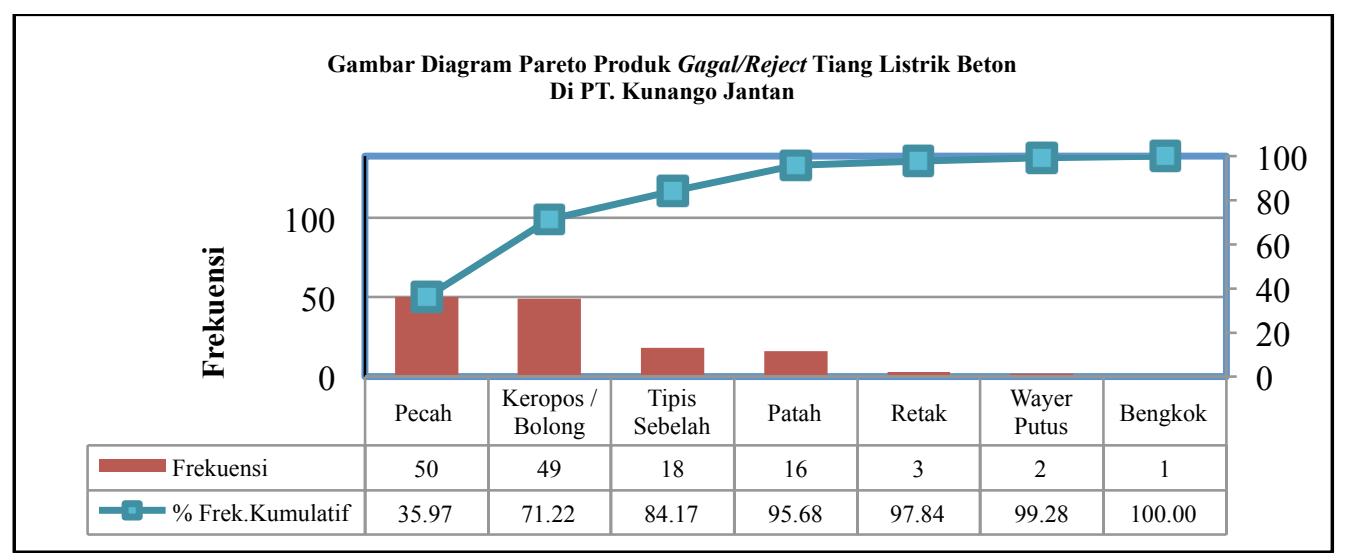

Gambar 4.Diagram Pareto Produk Gagal/Reject Tiang Listrik Beton Di PT. Kunango Jantan

\section{Affinity Diagram}

Affinity Diagram merupakan diagram yang digunakan untuk mengumpulkan permasalahanpermasalahan yang terjadi selama proses produksi PT. Kunango Jantan yang didapat dari hasil wawancara terhadap pegawai yang terlibat dalam proses produksi tersebut dan juga dari observasi secara langsung. Kemudian permasalahan yang didapat akan dikelompokan berdasarkan jenis-jenis permasalahannya. Berikut ini adalah tabel daftar permasalahan yang dihadapi PT. Kunango Jantan:

1. Produk Gagal/Reject Kategori Pecah

Berikut merupakan tabel daftar permasalahan yang mengakibatkan produk gagal/reject kategori pecah:

Tabel 4. Daftar Permasalahan yang Mengakibatkan Tiang Listrik Beton Pecah

\begin{tabular}{|c|l|}
\hline No & Daftar Kesalahan \\
\hline 1 & Pengawas tidak mengawasi secara berkala \\
\hline 2 & Bahan baku berkualitas buruk \\
\hline 3 & Pengadukan bahan tidak sesuai waktu \\
\hline 4 & Pengangkatan produk tidak seimbang \\
\hline 5 & Posisi kerja yang salah \\
\hline 6 & Mesin kurang perawatan \\
\hline 7 & Lingkungan kerja berisik \\
\hline 8 & Lingkungan kerja becek \\
\hline 9 & Lingkungan kerja berserakan \\
\hline
\end{tabular}

Berdasarkan tabel 4. maka jenis-jenis kesalahan yang didapatkan dikelompokkan menjadi beberapa kelompok seperti pada gambar 5. berkut:

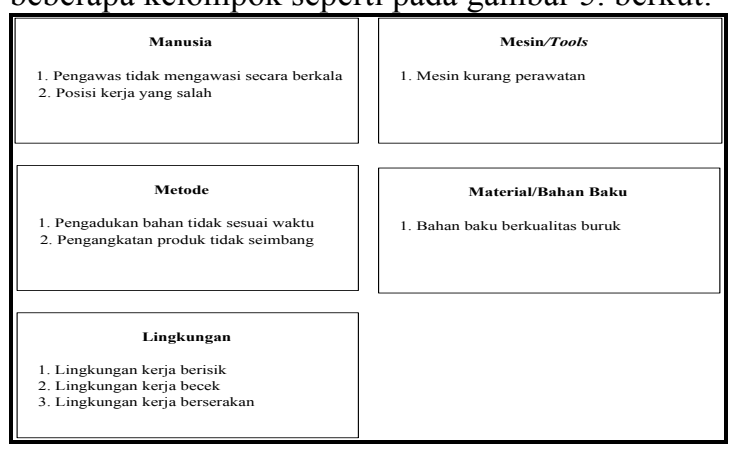

Gambar 5.Afinity Diagram Produk Gagal/Reject Kategori Pecah
2. Produk Gagal/Reject Kategori Keropos/Bolong

Berikut merupakan tabel daftar permasalahan yang mengakibatkan produk gagal/reject kategori keropos/bolong:

Tabel 5. Daftar Permasalahan Yang Mengakibatkan Tiang Listrik Beton Keropos/Bolong

\begin{tabular}{|c|l|}
\hline No & \multicolumn{1}{|c|}{ Daftar Kesalahan } \\
\hline 1 & Bahan baku berkualitas buruk \\
\hline 2 & $\begin{array}{l}\text { Karyawan kurang memeriksa pemasangan } \\
\text { material }\end{array}$ \\
\hline 3 & Tidak ada pengawasan \\
\hline 4 & Pemutaran mesin spinning tidak standar \\
\hline 5 & Lingkungan kerja berserakan \\
\hline 6 & Kurangnya pembersihan moulding \\
\hline 7 & Kurangnya pengisian bahan beton \\
\hline 8 & Takaran bahan tidak seimbang \\
\hline
\end{tabular}

Berdasarkan tabel 5. diatas maka jenisjenis kesalahan yang didapatkan dikelompokkan menjadi beberapa kelompok seperti pada gambar 6 . berkut:

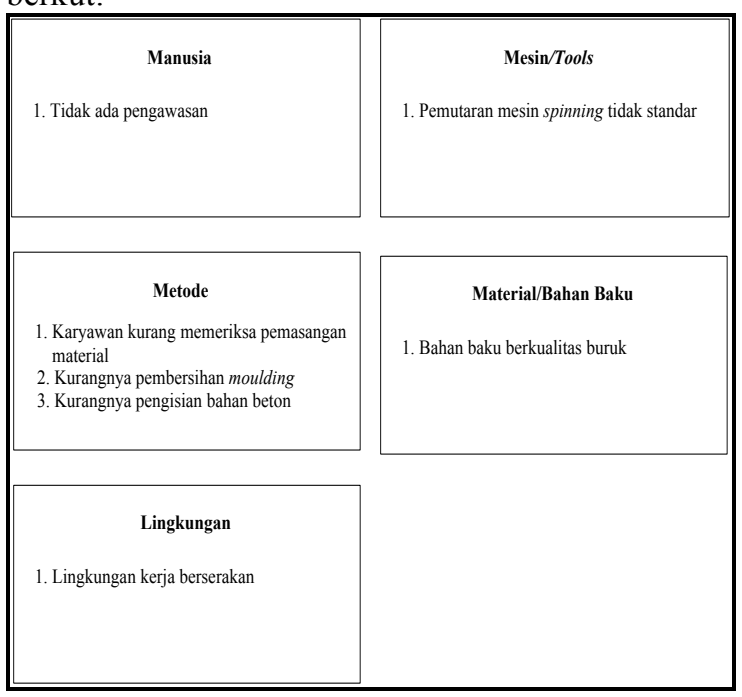

Gambar 6.Afinity Diagram Produk Gagal/Reject Kategori Keropos/Bolong

3. Produk Gagal/Reject Kategori Tipis Sebelah 
Berikut merupakan tabel daftar permasalahan yang mengakibatkan produk gagal/reject kategori tipis sebelah:

Tabel 6. Daftar Permasalahan yang Mengakibatkan Tian\$Listrik Beton Tipis Sebelah

\begin{tabular}{|c|l|}
\hline No & \multicolumn{1}{c|}{ Daftar Kesalahan } \\
\hline 1 & Bahan baku berkualitas buruk \\
\hline 2 & Tidak ada pengawasan \\
\hline 3 & Kurangnya pengisian bahan beton \\
\hline 4 & Moulding bengkok/baling \\
\hline 5 & Pemutaran mesin spinning tidak standar \\
\hline 6 & Pengangkatan produk tidak seimbang \\
\hline 7 & Lingkungan kerja becek \\
\hline 8 & Lingkungan kerja berserakan \\
\hline
\end{tabular}

Berdasarkan tabel 6. maka jenis-jenis kesalahan yang didapatkan dikelompokkan menjadi beberapa kelompok seperti pada gambar 7 . berikut:

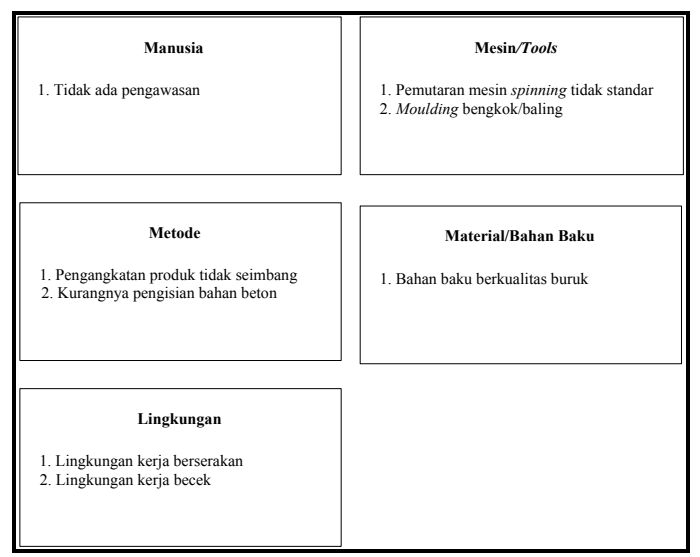

Gambar 7.Afinity Diagram Produk Gagal/Reject Kategori Tipis Sebelah

\section{Diagram Fishbone}

Diagram ini merupakan diagram yang memperlihatkan terjadinya sebab-akibat terjadinya suatu permasalahan.Berikut merupakan analisa kecacatan produk yang diprioritaskan untuk perbaikan :

1. Akibat Produk Gagal/Reject Kategori Pecah.

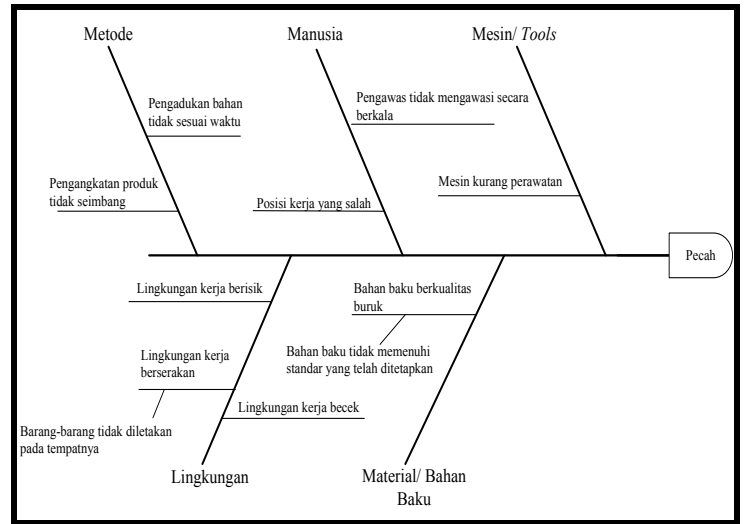

Gambar 8. Diagram Sebab-Akibat Produk Gagal/Reject Kategori Pecah
2. Akibat Produk Gagal/Reject Kategori Keropos/Bolong.

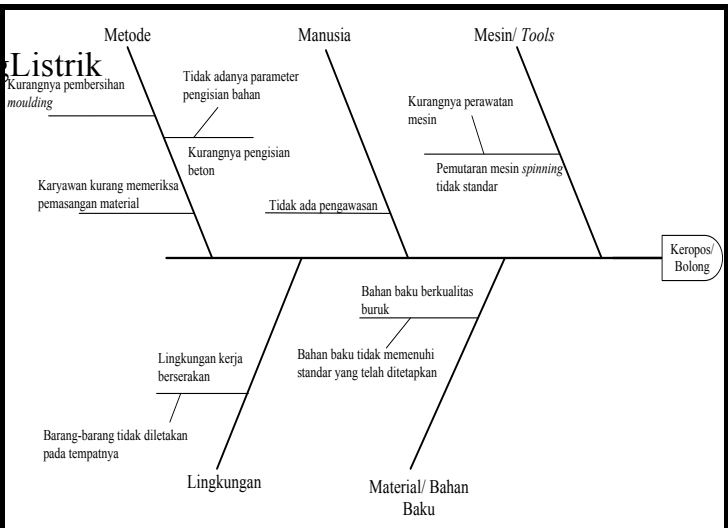

Gambar 9. Diagram Sebab-Akibat Produk Gagal/Reject Kategori Keropos/Bolong

3. Akibat Produk Gagal/Reject Kategori Tipis Sebelah.

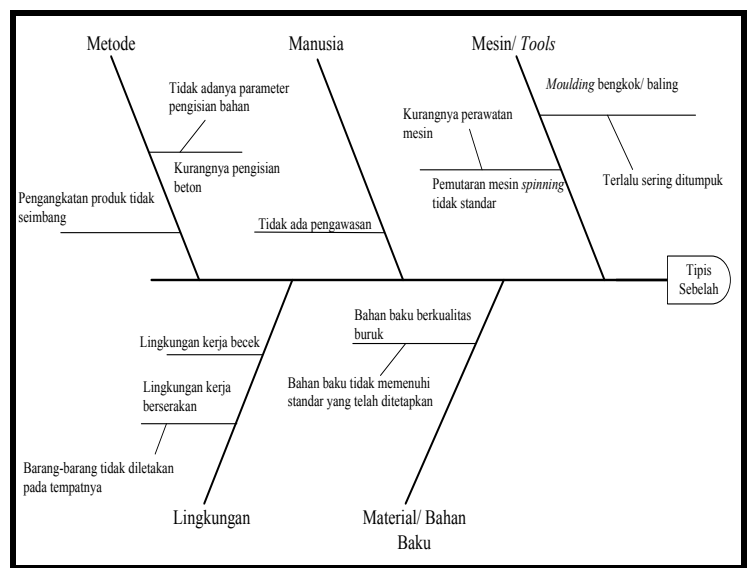

Gambar 10. Diagram Sebab-Akibat Produk Gagal/Reject Kategori Tipis Sebelah

\section{Tree diagram}

Tree diagram adalah suatu urutan proses yang dapat dilakukan agar mutu yang diinginkan tercapai. Berdasarkan penyebab dan faktor terjadinya produk gagal/reject maka pada gambar 11. adalah langkah-langkah yang harus dilakukan untuk mengurangi produk gagal/reject kategori pecah, kategori keropos/bolong dan kategori tipis sebelah. 


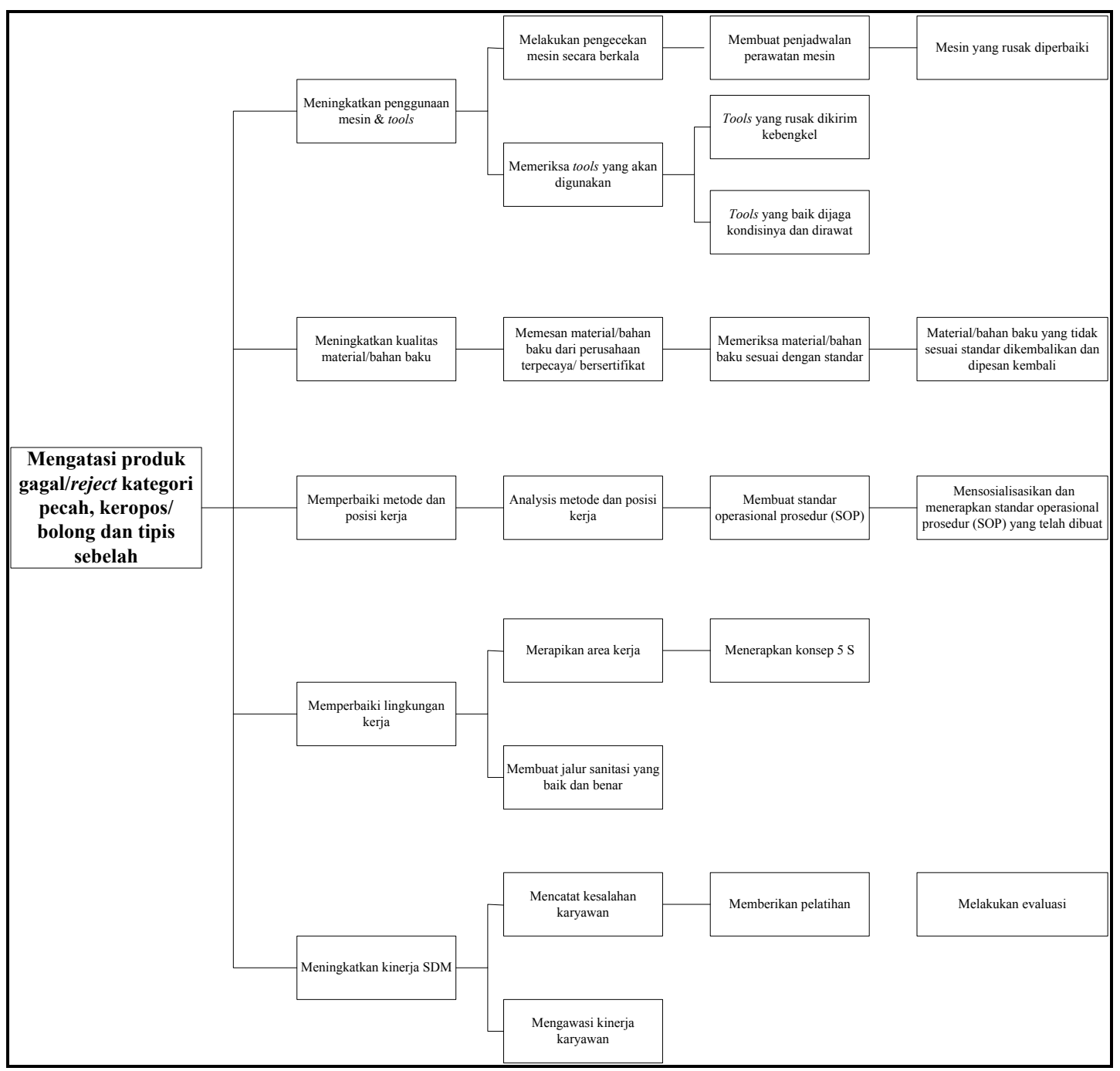

Gambar 11.Tree Diagram Produk Gagal/Reject Kategori Pecah, Keropos/Bolong dan Tipis Sebelah

Analisa Process Decision Program Chart (PDPC)

Metode ini digunakan untuk memetakan semua peristiwa dan kejadian yang mungkin terjadi ketika berpindah dari pernyataan masalah menuju kemungkinan solusi berdasarkan dari diagram pohon yang telah dibuat kemudian dilakukan evaluasi kelayakan penerapan program. Tahapan dari metode dimulai dari proses mengambil keputusan masing-masing cabang dari suatu diagram pohon, mengantisipasi masalah yang mungkin timbul dan menyediakan cara mengatasi masalah tersebut yang akan mencagah penyimpangan terjadi atau siap sedia jika penyimpangan terjadi. Analisa process decision program chart dilakukan pada penelitian ini adalah sebagai berikut: 


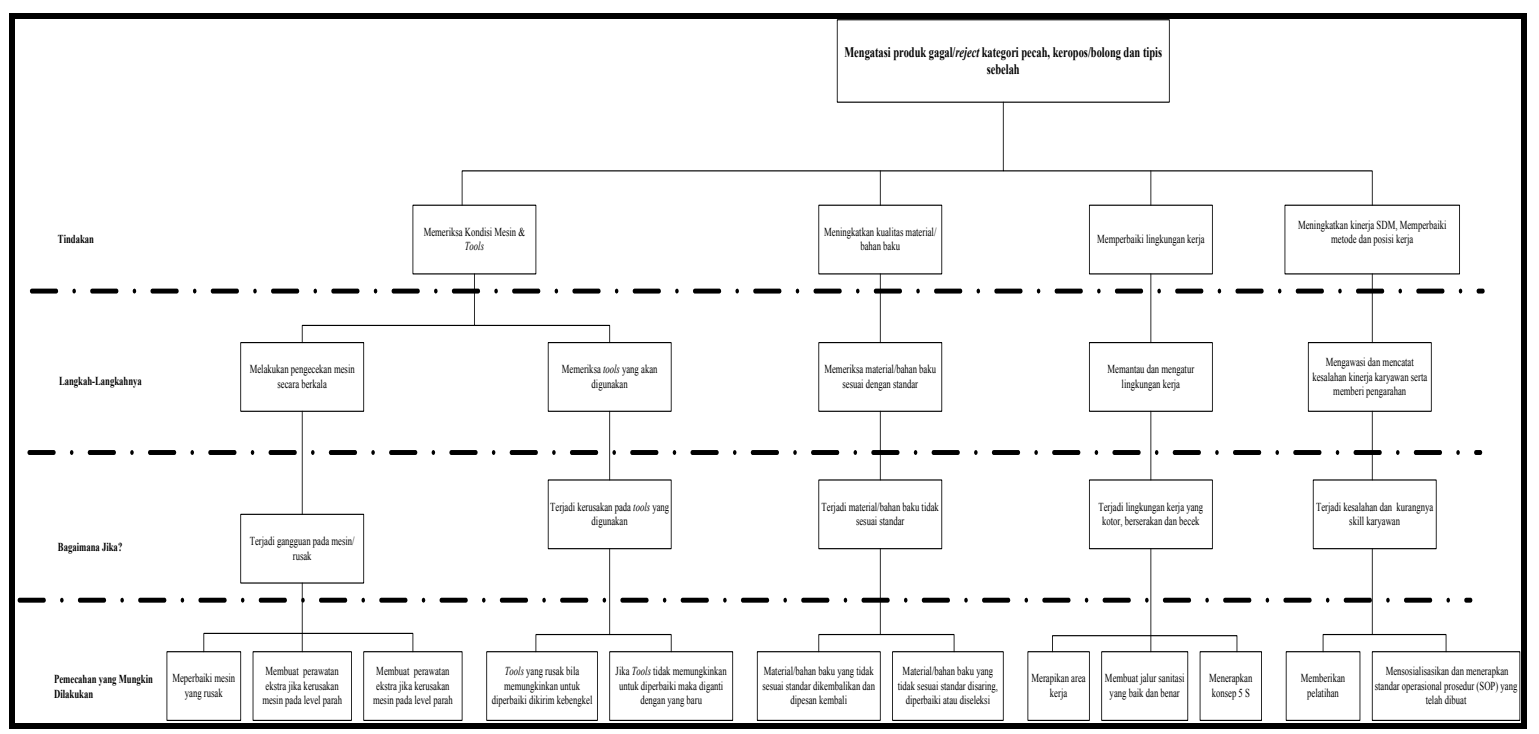

Gambar 12. Process Decision Program Chart Pada Produk Gagal/Reject Kategori Pecah, Keropos/Bolong Dan Tipis Sebelah

\section{Kesimpulan}

Berdasarkan penelitian yang dilakukan diketahui bahwa ada tujuh jenis kategori produk gagal/reject yaitu kategori Pecah, Keropos/Bolong, Tipis Sebelah, Patah, Retak, Wayer Putus dan Bengkok. Namun yang menjadi perhatian penuh untuk diperbaiki menurut diagram pareto hanya ada tiga jenis kategori (Pecah, Keropos/Bolong dan Tipis Sebelah), dimana faktor-faktor penyebab terjadinya produk gagal/reject ini yaitu Mesin/Tools, dimana pada ada perputaran mesin spinning tidak standar, moulding yang digunakan baling/bengkok serta mata bor yang digunakan tumpul/bengkok. Kemudian kualitas bahan baku yang buruk lalu lingkungan kerja berisik, becek dan berserakan serta SDM (Manusia) yang kurangnya tanggung jawab kerja.Adapun tindakan yang harus dilakukan oleh PT. Kunango Jantan untuk meningkatkan kualitas produknya yaitu memperbaiki mesin/tools yang rusak dan jika perlu menggantinya dengan yang baru, membuat jadwal perawatan/maintenance mesin/tools secara berkala. Dari segi bahan baku yaitu dengan mengembalikan bahan baku yang tidak sesuai standar dan dipesan kembali dengan kualitas yang lebih baik. Untuk lingkungan Kerja yaitu dengan merapikan lingkungan kerja dengan menggunakan prinsip $5 \mathrm{~S}$ dan untuk SDM (Manusia) yaitu dengan cara memberikan pelatihan kepada karyawan.

Adapun saran untukyang peneliti berikan yaitu Untuk mengurangi jumlah kecacatan produk, sebaiknya perusahaan melakukan tindakan preventif yaitu dengan mengontrol segala jenis kegiatan yang akan menimbulkan potensi untuk terjadi produk gagal/reject karena apabila produk gagal/reject dapat dikurangi maka biaya produksi dapat diminimalisir.

\section{Daftar Pustaka}

Bakhtiar,S,Dkk. (2013), “Analisa Pengendalian Kualitas dengan Menggunakan Metode Statistical Quality Control". Malikussaleh Industrial Engineering Journal Vol.2 No.1(2013)29-36, ISSN 2302 934X.

Darjanto, H. (2004), "Pengendalian dan Evaluasi Kualitas Beton Dengan Metode Statistical Process Control (SPC)" vol.4, No.2

Ginting,R. (2007), "Sistem Produksi" Penerbit Graha Ilmu : Bandung

Ivanto, M. (2010), “ Pengendalian Kualitas Produksi Koran Menggunakan Seven Tools Pada Pt. Akcaya Pariwara Kabupaten Kubu Raya" Universitas Tanjungpura.

Kaban, R. (2014). " Pengendalian Kualitas Kemasan Plastik Pouch Menggunakan Statistical Procces Control (SPC) Di Pt Incasi Raya Padang" Jurusan Teknik Industri, Fakultas Teknik, Universitas Andalas, Padang. ISSN 2088-4842.

Milawati,C,Dkk. (2005), "Sistem Pengendalian Kualitas dengan Bantuan Expert System untuk Menurunkan Tingkat Kecacatan Produk". Universitas Kristen Petra :

Papilo,P.(2010),"Pengendalian Kualitas Produksidan Menurut Hukum Islam", Penerbit Suska Press : Pekanbaru.

Parwati, Indri,C \& Sakti,M,R. (2012), "Pengendalian Produk Cacat dengan Pendekatan Kaizen dan Analisis Masalah dengan Seven Tools", Prosiding Seminar 
Nasional Aplikasi Sains \& Teknologi (SNAST)

Periode III Yogyakarta.

Purnomo,E. (2006), "Pengaruh Quality Control Terhadap Tingkat Kerusakan Produk pada PT.Filma Utama Soap Surabaya”. Administrasi Bisnis FISIP-UPN"Veteran" : Jawa Timur

Subagio, S, A. (2010), "Tinjauan kejut beton mutu tinggi dengan penambahan silica fume, fly ash dan serat baja” Jurusan Teknik Sipil Fakultas Teknik Universitas Sebelas Maret Surakarta.

Tanjong,S. (2013), "Implmentasi Pengendalian Kualitas dengan Metode Statistik pada Pabrik Spareparts CV Victory Metallurgy Sidoarjo". Universitas Surabaya : Surabaya. 